\title{
Comparative analysis of follistatin-, activin beta A- and activin beta B-mRNA steady-state levels in diverse porcine tissues by multiplex $S 1$ nuclease analysis
}

\author{
Olaf Schneider, Roland Nau and Uwe Michel \\ Department of Neurology, University of Göttingen, Robert-Koch-Strasse 40, 37075 Göttingen, Germany \\ (Correspondence should be addressed to U Michel, Laboratory of Neurobiology, Department of Neurology, University of Göttingen, von-Siebold-Strasse \\ 5, 37075 Göttingen, Germany; Email: umichel@gwdg.de)
}

\begin{abstract}
Objective: The relation of activins (dimers of the beta-subunits of inhibin) and follistatin (FS) (their binding protein) affect the growth and differentiation of many cell types. Activin- and FS-mRNAs show a widespread co-expression throughout the organism, indicating an essential role for the FS/activin system in diverse physiological processes. The present study was performed to investigate FS-, activin beta A-, and activin beta B-mRNA expression in porcine tissues and to compare the relative mRNA tissue distribution by a newly developed multiplex S1 nuclease protection assay.

Methods: Twenty micrograms total RNA from different porcine tissues were subjected to multiplex S1 analysis. Specific mRNA expression was determined by measurements of optical densities on autoradiographs.

Results: Activin beta A-mRNA expression was abundant in the ovary, adrenal gland, fat, vein, artery and uterus, activin beta B-mRNA was highly expressed in the ovary, pituitary, uterus, placenta, aorta and cerebellum. FS-mRNA showed a widespread expression with high levels in ovary, uterus, cerebellum, placenta and fat. The comparison of relative activin beta A-, activin beta B- and FSmRNA expression within a certain tissue showed a predominance of activin beta A-mRNA in the adrenal gland, fat, artery, spinal cord, cerebrum and colon and of activin beta B-m RNA in pituitary, testis and placenta, while FS-mRNA levels exceeded those of activin subunits in epididymis, liver, lymphoid tissue, muscle, intestine, cerebellum, ovary and uterus.

Conclusions: The presented data provide an overview of FS-, activin beta A-, and activin beta B-mRNA steady state levels in porcine tissues.
\end{abstract}

European Journal of Endocrinology 142 537-544

\section{Introduction}

Activins are homo- or heterodimers consisting of two homologous beta-inhibin peptide chains structurally related to the transforming growth factor beta family. The most common forms are activin A (beta A-beta A), activin $\mathrm{AB}$ (beta A-beta $\mathrm{B}$ ) and activin $\mathrm{B}$ (beta B-beta $\mathrm{B}$ ) $(1,2)$. As growth and differentiating factors, activins are involved in the regulation of multiple biological systems including pituitary hormone secretion $(2-5)$, spermatogenesis (6), erythropoesis $(7,8)$, embryonic development $(9,10)$ and neural differentiation $(11,12)$. Recently, three additional beta-inhibin subunits have been discovered (beta $\mathrm{C}$, beta $\mathrm{D}$ and beta $\mathrm{E}$ ), but so far little is known about their physiological significance (13-15). The biological actions of activins are mediated by a heterotrimeric complex of activin and membranebound activin receptors type I and II with serine/ threonine kinase activity $(16,17)$.
Activin is bound by follistatin (FS), a $32-35 \mathrm{kDa}$ single-stranded glycoprotein $(18,19)$ in a highaffinity com-plex that itself seems biologically inactive (20). FS inhibits the interaction of activin with its type II receptor (21), and heparan sulfate-bound FS at the cell surface accelerates intracellular activin A uptake and lysosomal degradation in rat pituitary cells in vitro (22). As outlined above, the FS/activin system is involved in the paracrine regulation of multiple tissues. In contrast to inhibin, where endocrine effects are well established (23), possible systemic endocrine FS/activin effects are still under debate (24).

Earlier studies focused on the measurement of activin beta A-, activin beta B- or FS-mRNA expression in diverse tissues to determine those organs in which FS/ activin interactions might be important for proliferation and differentiation. A broad tissue distribution of activin- and FS-mRNA in rat tissues with the highest levels in ovary and testis was shown by S1 nuclease 
analysis $(25,26)$. Tuuri et al. (27) demonstrated a widespread expression of activin- and FS-mRNA in human fetal tissues, suggesting an important role of FS and activin in human development. Since then the expression of FS- and activin-mRNA has been detected in many non-gonadal tissues throughout the organism, and this has increased the interest in non-gonadal effects of the FS/activin system. Recent results showed the regulation of FS and activin in inflammation, acute phase response and tissue repair $(28,29)$, arteriosclerosis (30), pulmonary fibrosis (31), liver cirrhosis (32) and ischemic brain injury (33). Although a wealth of data has been accumulated about FS/activin expression in different organs, the source of circulating FS and activin protein in serum has not yet been determined and the naturally occurring ratios of FS- and activinsubunit-mRNAs under physiological conditions are still unknown.

In this study we focused on the tissue distribution of FS-, activin A- and activin-B-mRNAs. Our data should facilitate the analysis of paracrine effects of the FS/ activin system and add to earlier work on inhibin subunits (25). For this purpose, we developed a singletube multiplex S1 nuclease assay which permits the direct comparison of FS-, activin beta A- and activin beta B-mRNA expressions. We used this assay to analyze the distribution of activin beta A-, activin beta B- and FS-mRNA expressions in porcine tissues, and to compare the relative ratios of the specific mRNAs within each tissue.

\section{Materials and methods}

Yeast tRNA was from Boehringer (Mannheim, Germany), herring sperm DNA type XIV and BSA fraction V from Sigma (Deisenhofen, Germany), S1 nuclease (Aspergillus oryzae) from Pharmacia (Freiburg, Germany), SP6 and T7 RNA polymerases and restriction enzymes from Promega (Heidelberg, Germany), and [ $\left.{ }^{32} \mathrm{P}\right] \mathrm{UTP}(20 \mu \mathrm{Ci} /$ $\mu \mathrm{l})$ from Amersham Buchler (Braunschweig, Germany). All further chemicals and reagents were purchased in the purest grade available.

\section{Preparation of RNA from tissues and cell cultures}

Porcine tissues were prepared from 9-month-old freshly slaughtered female pigs (Sus scrofa ferus) from the local slaughterhouse (except for testis and epididymidis, which were taken from postpubertal 7-month-old male pigs), rapidly frozen in liquid nitrogen and stored at $-80^{\circ} \mathrm{C}$ until use. Arterial tissue was removed from the thoracic aorta and venous tissue from the superior vena cava. Lymphatic tissue was taken from paraaortal lymphatic nodes. RNA preparation using guanidine isothiocyanate and $\mathrm{CsCl}$ was performed according to standard methods (34). RNA was dissolved in $\mathrm{H}_{2} \mathrm{O}$ to a concentration of $1.0-2.5 \mu \mathrm{g} / \mu \mathrm{l}$. The integrity of each sample was checked by analyzing an aliquot on an ethidium bromide-stained, nondenaturing agarose gel and the amount of RNA was determined by measuring the optical density at $260 \mathrm{~nm}$. Cell cultures from endothelial cells of porcine aorta and porcine brain microvessels as well as RNA from the cell cultures were prepared exactly as described recently (34).

\section{PCR products and complementary RNA probes}

RNA was extracted form porcine ovaries, and first strand cDNA was produced with random primers according to standard methods (35). The design of the specific PCR products and complementary cRNA probes for porcine follistatin, activin beta A and beta B was described elsewhere (34). All clones were sequenced to confirm the identity of the cloned fragments.

In a first set of experiments the plasmid containing the beta B subunit was cut with EcoRI to produce a $474 \mathrm{bp}$ long cRNA probe. The $273 \mathrm{bp}$ FS insert corresponding to the last $153 \mathrm{bp}$ of exon 5 and the first 71 bp of exon 6 was cut with EcoRI and the plasmid containing the $194 \mathrm{bp}$ beta A subunit insert was cut with HincII. After multiplex S1 nuclease analysis, the appropriate sizes of the digested fragments were $432 \mathrm{bp}$ for beta B, $222 \mathrm{bp}$ for FS and $180 \mathrm{bp}$ for beta A. In vitro transcription of the beta A plasmid produced neotranscripts, which caused high background levels. Therefore, in further experiments the plasmids were cut in a different way: the beta B plasmid was cut with NARI, the FS plasmid was cut with EcoRI and the beta A plasmid was cut with KPN2I. The respective sizes of the digested fragments were $410 \mathrm{bp}$ for beta A, $333 \mathrm{bp}$ for beta $\mathrm{B}$ and $222 \mathrm{bp}$ for FS.

\section{In vitro transcription}

For in vitro transcription the Gemini-kit (Promega) was used following the manufacturer's instructions. Antisense cRNAs for all plasmids were transcribed with T7 polymerase. Each radioactively labeled cRNA for FS, activin beta $\mathrm{A}$ and beta $\mathrm{B}$ was resuspended in a phosphate buffer $\left(0.05 \mathrm{~mol} / \mathrm{l} \mathrm{Na}_{2} \mathrm{HPO}_{4} / \mathrm{NaH}_{2} \mathrm{PO}_{4}\right.$, (pH 7.2) $0.7 \%$ sodiumdodecylsulfate (SDS), $0.1 \mathrm{mmol} / \mathrm{l}$ EDTA and $0.1 \%$ BSA fraction $\mathrm{V}$ ) to a final concentration of 300 000-350 000 c.p.m./ $\mu$ l. Aliquots of each labeled cRNA (10 000000 c.p.m. (i.e. 28-33 $\mu \mathrm{l}$ )) were transferred to $900 \mu \mathrm{l}$ hybridization buffer $(150 \mu \mathrm{l} 0.5 \mathrm{~mol} / \mathrm{l}$ PIPES pH $6.8,120 \mu \mathrm{l} 5 \mathrm{~mol} / \mathrm{l} \mathrm{NaCl}, 6 \mu \mathrm{l} 0.5 \mathrm{~mol} / \mathrm{l}$ EDTA and $624 \mu \mathrm{l} \mathrm{H}_{2} \mathrm{O}$ ) and phosphate buffer was added to make up to a final volume of $1000 \mu \mathrm{l}$. The concentration of the phosphate buffer in the hybridization buffer was $10 \%$ and the final concentration of each labeled cRNA was approximately 10000 c.p.m./ $/$ l. 


\section{Multiplex S1 nuclease analysis}

Twenty micrograms total RNA or yeast tRNA (negative control) were dissolved in $20 \mu \mathrm{l} \mathrm{H}_{2} \mathrm{O}$, and then $10 \mu \mathrm{l}$ hybridization buffer including the labeled cRNAs (10 000 c.p.m./ $\mu \mathrm{l}$ of each probe) were added to each tube. The hybridization mix was gently vortexed, centrifuged and two drops of mineral oil (Sigma) were added to each sample to avoid evaporation during the hybridization. The tubes were heated to $100{ }^{\circ} \mathrm{C}$ for $3 \mathrm{~min}$ and then immediately transferred to the incubator; hybridization was performed at $80^{\circ} \mathrm{C}$ for $3 \mathrm{~h}$.

After incubation, $470 \mu \mathrm{l}$ digestion buffer (per sample: $5 \mu \mathrm{l} 5 \mathrm{~mol} / \mathrm{l} \mathrm{NaCl}, 5 \mu \mathrm{l} 3 \mathrm{~mol} / \mathrm{l} \mathrm{Na}$-acetate $\mathrm{pH} 4.6,5 \mu \mathrm{l}$ herring sperm DNA $(10 \mu \mathrm{g} / \mu \mathrm{l}), 20 \mu \mathrm{l} 0.1 \mathrm{~mol} / \mathrm{l} \mathrm{ZnSO}_{4}$, $480 \mu \mathrm{l} \mathrm{H}_{2} \mathrm{O}$ and $350 \mathrm{U} \mathrm{S1}$ nuclease) were added to each sample. The tubes were gently vortexed and centrifuged. Digestion was performed in a water bath for $60 \mathrm{~min}$ at $37^{\circ} \mathrm{C}$. The reaction was stopped by adding $100 \mu \mathrm{l}$ $4 \mathrm{~mol} / \mathrm{l}$ ammonium acetate $/ 0.1 \mathrm{~mol} / \mathrm{l}$ EDTA. Each sample was precipitated with $700 \mu \mathrm{l}$ isopropanol containing $1 \mu \mathrm{l}$ dextran blue $(20 \mu \mathrm{g} / \mu \mathrm{l})$ per sample and $20 \mu \mathrm{g}$ yeast tRNA and washed with $500 \mu \mathrm{l} 70 \%$ ethanol. The addition of dextran blue to the isopropanol resulted in a solid blue-coloured pellet, which minimized the loss of pellets during the precipitation step. The samples were resuspended in $5 \mu \mathrm{l} \mathrm{TE}$ (10 mM TRIS, $1 \mathrm{mM}$ EDTH) $\mathrm{pH} 8$ plus $4 \mu \mathrm{l}$ loading buffer $(80 \%$ formamide; $10 \mathrm{mmol} / \mathrm{l}$ EDTA $\mathrm{pH} 8 ; 1 \mathrm{mg} / \mathrm{ml}$ xylene cyanol $\mathrm{FF}$ and $1 \mathrm{mg} / \mathrm{ml}$ bromophenol blue). Samples were heated for $3 \mathrm{~min}$ to $90^{\circ} \mathrm{C}$ and kept on ice for another $3 \mathrm{~min}$. Thereafter, $2.5 \mu \mathrm{l}$ aliquots were loaded on denaturing acrylamide gels ( $7 \%$ acrylamide $/ 8 \mathrm{~mol} / \mathrm{l}$ urea). Autoradiography was performed on X-ray films with intensifying screens at $-80^{\circ} \mathrm{C}$ for varying time spans.

\section{Data analysis and presentation}

Hybridization signals on X-ray films were scanned with an Epson 9000 scanner and the Epscan-ScanPack 2 software analysis program. Quantification of the signals was achieved with the NIH Image 1.54 program. If the FS signals consisted of double bands as sometimes observed in earlier studies (36), both bands were scanned for quantification. To ensure the use of equal amounts of total RNA for each S1 nuclease analysis, total RNA was quantified by optical density measurements, and integrity of the RNA was examined by non-denaturing agarose gels (as described in Materials and methods). Data presented in the figures represent results confirmed in at least two other similar experiments.

\section{Results}

\section{Evaluation of the multiplex S1 nuclease protection assay}

To determine the accuracy and the linearity of the mRNA measurements, standard curves using 2.5, 5, 10 and $20 \mu \mathrm{g}$ total RNA from porcine ovary, cultured endothelial cells from porcine aorta (AEC) and from porcine brain microvessels (BMVEC) were produced. Figure 1 summarizes the results of activin beta A-, beta B- and FS-mRNA expression in these tissues and demonstrates the reproducibility of the measurements in the range from 2.5 to $20 \mu \mathrm{g}$ total RNA. There was no obvious interference between the three labeled plasmids (Fig. 1A). Activin beta B-mRNA was not detectable in AEC (Fig. 1B), and FS-mRNA was not detectable in 2.5 and $5 \mu \mathrm{g}$ but was detectable in 10 and $20 \mu \mathrm{g}$ total RNA from BMVEC (Fig. 1C).

\section{Distribution of activin beta A-, beta B- and FS-mRNA in different porcine tissues}

The distribution of activin beta A-, beta B- and FSmRNA in porcine tissues is demonstrated in Fig. 2. Highest steady state levels of all three mRNAs were found in the ovary. FS showed a widespread expression with high levels in ovary, uterus, cerebellum, placenta and fat, while it was below the limit of detection in pituitary, spinal cord, testis, blood cells, and stomach (latter two not shown) (Fig. 2A). An unexpected result was the FS-mRNA levels in the kidney which revealed a high individual variation between different analyses. Activin beta A-mRNA expression was abundant in the ovary, adrenal gland, fat, vein, artery and uterus. We could not find specific signals for activin beta A-mRNA in lymphoid tissue, pituitary, epididymis, muscle, lung, intestine, liver, blood cells and stomach (latter two not shown) (Fig. 2B). Activin beta B-mRNA was highly expressed in the ovary, pituitary, uterus, placenta, thoracic aorta and cerebellum. No specific signal could be detected in lymphoid tissue, adrenal gland, epididymis, fat, muscle, heart, kidney, gut, liver, blood cells and stomach (latter two not shown) (Fig. 2C).

\section{Comparison of relative activin beta $A-$, activin beta B-and FS-mRNA levels within single porcine tissues}

In order to compare the proportion of activin beta A-, activin beta B- and FS-mRNA expressions in a certain porcine tissue, the relative ratios of the specific signals (as a percentage of the total radioactivity detected) are listed in Table 1. Activin beta A-mRNA predominated in the adrenal gland, fat, artery, vein and spinal cord. For activin beta $B$ the relative amount was highest in pituitary, testis and placenta. No specific signals for activin beta A- and activin beta B-mRNA were detectable in epididymis, liver, lymphoid tissue, muscle and intestine, making FS-mRNA the predominant RNA in those tissues; FS also dominated in heart, cerebellum, ovary and uterus. 

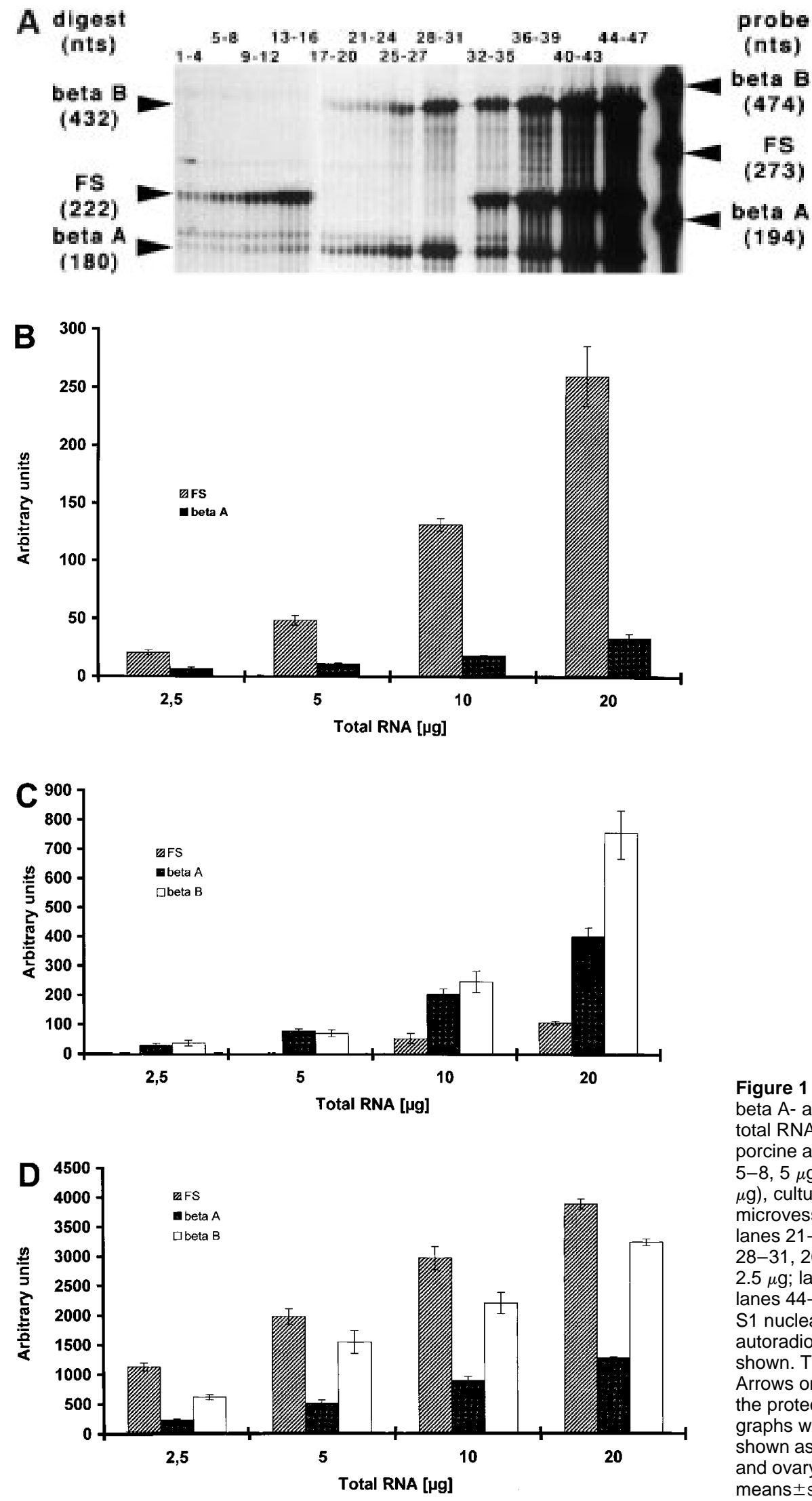

Figure 1 (A) Steady state levels of FS-, activin beta A- and activin beta B-mRNA in 2.5-20 $\mu \mathrm{g}$ total RNA from cultured endothelial cells of the porcine aorta (AEC) (lanes 1-4, $2.5 \mu \mathrm{g}$; lanes 5-8, $5 \mu \mathrm{g}$; lanes 9-12, $10 \mu \mathrm{g}$; lanes 13-16, 20 $\mu \mathrm{g}$ ), cultured endothelial cells of porcine brain microvessels (BMVEC) (lanes 17-20, $2.5 \mu \mathrm{g}$; lanes 21-24, $5 \mu \mathrm{g}$; lanes 25-27, $10 \mu \mathrm{g}$; lanes $28-31,20 \mu \mathrm{g}$ ) and porcine ovary (lanes $32-35$, $2.5 \mu \mathrm{g}$; lanes 36-39, $5 \mu \mathrm{g}$; lanes $40-43,10 \mu \mathrm{g}$; lanes $44-47,20 \mu \mathrm{g}$ ) as determined by multiplex $\mathrm{S} 1$ nuclease analysis. On the right side of the autoradiograph $2 \mu \mathrm{l}$ of the undigested probes are shown. The sizes (bp) are indicated by arrows. Arrows on the left side indicate the sizes $(b p)$ of the protected fragments. (B, C, D) Autoradiographs were scanned and integration values are shown as arbitrary units for AEC (B), BMVEC (C) and ovary (D). The columns represent the means \pm S.D. of 3-4 separately assayed samples.

www.eje.org 

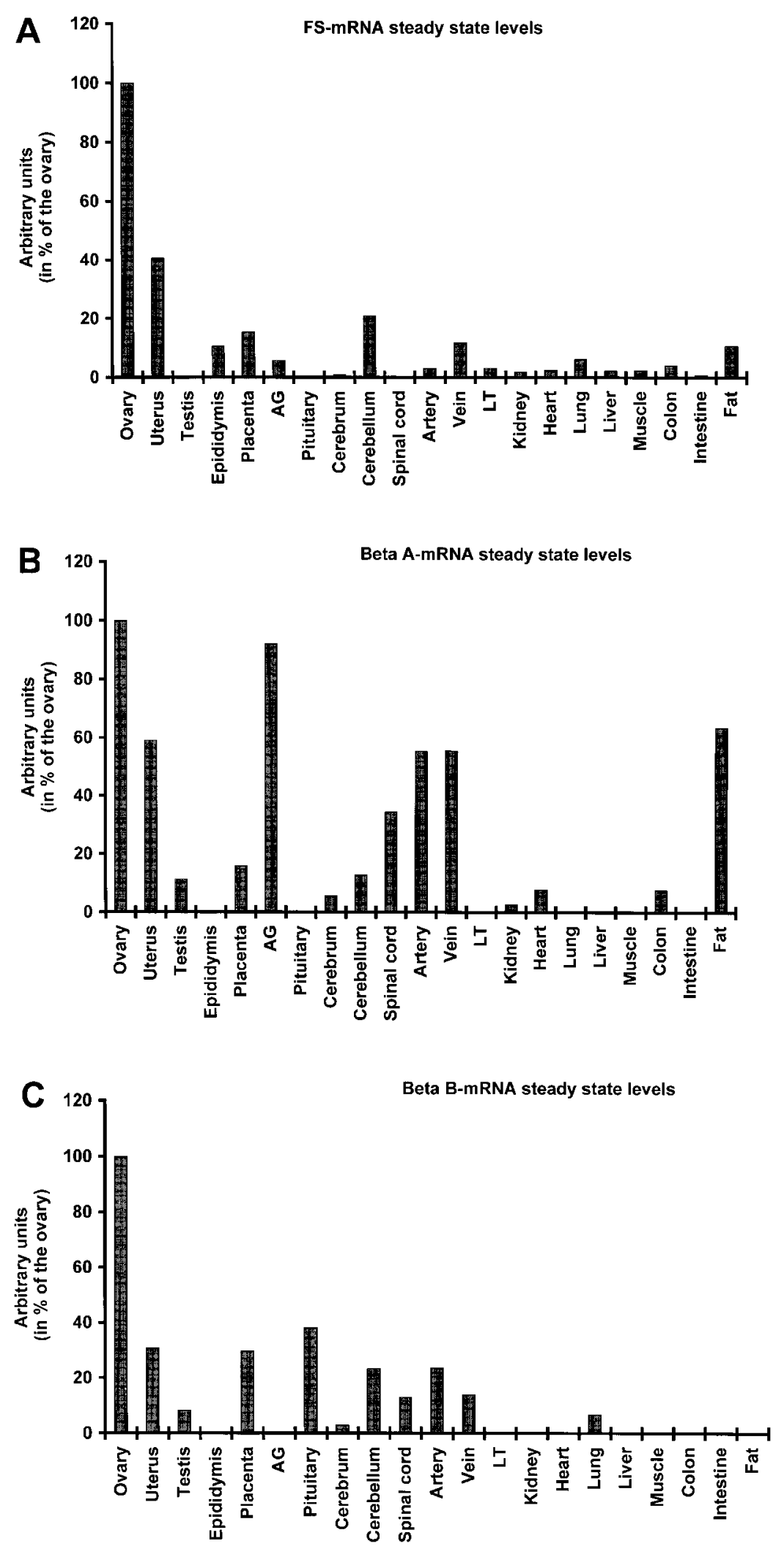

Figure 2 (A) FS-, (B) activin beta A- and (C) activin beta B-mRNA expression in $20 \mu \mathrm{g}$ total RNA from various porcine tissues measured by multiplex S1 nuclease analysis (AG: adrenal gland; LT: lymphoid tissue). Values are expressed in relation to the expression of the respective mRNA in the ovary $(100 \%)$. The values are representative of two further experiments. Blood cells and stomach did not display signals above background levels and are not included in the graphs. 
Table 1 Relative expressions of FS-, activin beta A- and activin beta B-mRNA in $20 \mu \mathrm{g}$ total RNA from porcine tissues as measured by multiplex S1 nuclease analysis. The values are representative of two similar experiments and are given as percentage of the total densitometric units of the respective tissue. Blood cells and stomach did not contribute signals above background levels and are not included in the table.

\begin{tabular}{lccc}
\hline Porcine tissues & FS & beta A & beta B \\
\hline Adrenal gland & 15.3 & 84.7 & b.l.d. \\
Artery & 8.2 & 52.3 & 39.5 \\
Cerebellum & 58.2 & 9.9 & 31.9 \\
Cerebrum & 18.5 & 42.8 & 38.7 \\
Colon & 45.6 & 54.4 & b.l.d. \\
Epididymis & 100 & b.l.d. & b.l.d. \\
Fat & 21.3 & 78.7 & b.l.d. \\
Heart & 66.1 & 33.9 & b.l.d. \\
Intestine & 100 & b.l.d. & b.l.d. \\
Kidney & 53.1 & 46.9 & b.l.d. \\
Liver & 100 & b.l.d. & b.l.d. \\
Lung & 55.5 & b.l.d. & 44.5 \\
Lymphoid tissue & 100 & b.l.d. & b.I.d. \\
Muscle & 100 & b.l.d. & b.l.d. \\
Ovary & 50.9 & 17.7 & 31.4 \\
Pituitary & b.l.d. & b.l.d. & 100 \\
Placenta & 39.2 & 14.0 & 46.8 \\
Spinal cord & b.l.d. & 59.9 & 40.1 \\
Testis & b.l.d. & 43.5 & 56.5 \\
Uterus & 50.6 & 25.7 & 23.7 \\
Vein & 29.5 & 48.9 & 21.6 \\
& & & \\
\hline
\end{tabular}

b.l.d., below the limit of detection.

\section{Discussion}

Activins and FS play an essential role in cell differentiation and proliferation in multiple tissues throughout the organism (2-12). While earlier work on activins and FS concentrated mainly on the effects of both proteins in endocrine and especially gonadal tissues, recent research has shown that both factors participate in the regulation of non-reproductive functions such as tissue repair and inflammation $(28,29)$. Since the actions of activin are neutralized by binding to FS, the physiological balance of both polypeptides is most important in activin-responsive tissues. Until now, no study has examined the relative amounts of mRNA steady state levels of all three polypeptides in multiple tissues of one species. For this reason, we developed a multiplex S1 nuclease assay to investigate the steady state levels of FS-, activin beta A- and beta B-mRNA in a variety of porcine tissues. The assay is based on an earlier published method (36), but has several advantages; it avoids poor dissolvability of RNA in high salt solutions, long hybridization times and loss of pellets during the precipitating step.

For evaluation of the assay, we performed an S1 nuclease analysis of FS-, activin beta A- and activin beta B-mRNA expression in 2.5, 5, 10 and $20 \mu \mathrm{g}$ total RNA from tissue (porcine ovary) and cell culture (AEC and BMVEC). The small variation of the quadruplicate samples in the standard curves demonstrates the reproducibility of the assay procedures. No signals for activin beta B-mRNA in AEC were detected. This was in contrast to earlier results performed with a single S1 nuclease analysis (34), where we could demonstrate activin beta B expression in AEC at a very low level. The difference is most likely caused by a slight decrease in sensitivity of the multiplex assay in comparison to the analysis of a single RNA. After long exposure times of the X-ray films, activin beta B-mRNA in AEC was visible. This, however, caused a massive overexpression of the stronger signals and an unacceptable increase of background signals. Therefore, the lack of detection of a certain RNA in a given tissue with our assay does not necessarily imply a complete lack of expression of the respective RNA, but that its expression is negligible in comparison to the detected subunits.

Meunier et al. (25) compared the expression of inhibin subunits in rat tissues and detected the highest level of beta A-mRNA in placenta and the ovary, followed by bone marrow, brain and spinal cord. Moderate signals were detected in spleen, adrenal and testis, while no expression of beta A-mRNA was found in the kidney, pancreas, liver and pituitary. Beta B-mRNA was detected in the ovary, pituitary, placenta, testis and brain. Our experiments yielded similar results in porcine tissues. Activin beta A-mRNA showed the highest expression in the ovary. It also predominated in the adrenal gland, fat tissue, vena cava, thoracic aorta and uterus. No specific signals were obtained in epididymis, pituitary, lymphoid tissue, lung, liver, muscle and intestine (Fig. 2B). The expression of beta B-mRNA was almost identical in rat (25) and porcine tissues (our study, Fig. 2C). Although the expression of a mRNA is the premise for the expression of the respective protein, it must be remembered that the occurrence of a specific mRNA does not necessarily imply its translation (37).

The tissue distribution of FS-mRNA in rat tissue was examined by Michel et al. (36): high levels of FS-mRNA were found in the ovary, kidney, muscle, uterus and cortex, while liver, spleen, blood cells and cerebellum did not display signals above background levels. The results of our study in porcine tissues showed a similar pattern, but we also found some significant exceptions. In contrast to earlier work with rat (36) and porcine tissues (38), the decreased sensitivity of our multiplex assay, in comparison to a single mRNA analysis (34), did not allow the detection of FS mRNA in porcine pituitaries. Nevertheless, the data clearly demonstrate the predominance of the beta $\mathrm{B}$ subunit mRNA in porcine pituitaries. Furthermore, we did not detect FSmRNA in testis, and the signals of the kidney and muscle were unexpectedly low (Fig. 2A). As it is known that steady state levels of FS vary during development (26), this discrepancy might be due to age differences. In an earlier study, 10- to 12-fold differences in the steady state levels of FS-mRNA were seen in the rat kidney during postnatal rat development (26). This 
study also demonstrated a high variation of FS-mRNA levels in the kidney. The high variation in kidney FS-mRNA levels was also seen in kidneys of adult mice, where RNA extracted from whole kidneys was used for analysis (O Schneider \& U Michel, unpublished observations).

The physiological role of the FS/activin system in vivo is still controversial. Circulating activin A in serum increases with age, but is not correlated with the increase in follicle-stimulating hormone $(24,39)$. The source of FS and activin in serum is still unknown and a variety of studies suggest that the gonads are not the major source of both peptides in serum (40). Besides other effects (see Introduction), activin participates, for example, in the regulation of inflammation (29) and neuroprotection $(41,42)$ and the relative amounts of FS and activin are likely to be crucial for the correct adjustment of the processes. Another factor which might influence the availability of beta subunits is the possible concomitant expression of the inhibin alpha subunit in a given tissue (see Meunier et al. (25)).

In summary, we developed a muliplex S1 nuclease assay for FS-, activin beta A- and beta B-mRNA and analyzed the steady state levels of these mRNAs in different porcine tissues. With this assay we demonstrated a high variation in the relation of activin subunits- and FS-mRNA in the tissues examined. The physiological ratios of FS-/activin-mRNAs are an important prerequisite for studies of the expression of these RNAs under pathophysiological conditions. Although the expression of a mRNA does not necessarily provide evidence for the synthesis of the respective polypeptide, these data might facilitate the localization of tissues or/and organs which contribute to systemic FS and activin peptide concentrations.

\section{Acknowledgement}

The authors wish to thank Dr Anthony Albiston for valuable discussion.

\section{References}

1 Ling N, Ying SY, Ueno N, Shimasaki S, Esch F, Hotta M et al. Pituitary FSH is released by a heterodimer of the beta-subunits from the two forms of inhibin. Nature 1986321 779-782.

2 Vale W, Rivier J, Vaughan J, McClintock R, Corrigan A, Woo W et al. Purification and characterization of an FSH releasing protein from porcine ovarian follicular fluid. Nature 1986321 776-779.

3 Kitaoka M, Kojima I \& Ogata E. Activin-A: a modulator of multiple types of anterior pituitary cells. Biochemical and Biophysical Research Communications 1988157 48-54.

4 Billestrup N, Gonzalez-Manchon C, Potter E \& Vale W. Inhibition of somatotroph growth and growth hormone biosynthesis by activin in vitro. Molecular Endocrinology 19904 356-362.

5 Sawchenko PE, Plotsky PM, Pfeiffer SW, Cunningham ET Jr, Vaughan J, Rivier J et al. Inhibin beta in central neural pathways involved in the control of oxytocin secretion. Nature 1988334 615-617.

6 Mather JP, Attie KM, Woodruff TK, Rice GC \& Phillips DM. Activin stimulates spermatogonial proliferation in germ-Sertoli cell cocultures from immature rat testis. Endocrinology 1990127 3206-3214.

7 Eto Y, Tsuji T, Takezawa M, Takano S, Yokogawa Y \& Shibai H. Purification and characterization of erythroid differentiation factor (EDF) isolated from human leukemia cell line THP-1 (published erratum appears in Biochemical and Biophysical Research Communications 1987144 (3) 1349). Biochemical and Biophysical Research Communications 1987142 1095-1103.

$8 \mathrm{Yu}$ J, Shao LE, Lemas V, Yu AL, Vaughan J, Rivier J et al. Importance of FSH-releasing protein and inhibin in erythrodifferentiation. Nature $1987330765-767$.

9 Thomsen G, Woolf T, Whitman M, Sokol S, Vaughan J, Vale Wet al. Activins are expressed early in Xenopus embryogenesis and can induce axial mesoderm and anterior structures. Cell 199063 485-493.

10 Hemmati-Brivanlou A, Kelly OG \& Melton DA. Follistatin, an antagonist of activin, is expressed in the Spemann organizer and displays direct neuralizing activity. Cell 199477 283-295.

11 Schubert D, Kimura H, LaCorbiere M, Vaughan J, Karr D \& Fischer WH. Activin is a nerve cell survival molecule. Nature 1990344 868-870.

12 Fann MJ \& Patterson PH. Neuropoietic cytokines and activin A differentially regulate the phenotype of cultured sympathetic neurons. Proceedings of the National Academy of Sciences of the USA $19949143-47$

13 Hötten G, Neidhardt H, Schneider C \& Pohl J. Cloning of a new member of the TGF-beta family: a putative new activin beta $\mathrm{C}$ chain. Biochemical and Biophysical Research Communications 1995 206 608-613.

14 Fang J, Yin W, Smiley E, Wang SQ \& Bonadio J. Molecular cloning of the mouse activin beta $\mathrm{E}$ subunit gene. Biochemical and Biophysical Research Communications 1996228 669-674.

15 Oda S, Nishimatsu S, Murakami K \& Ueno N. Molecular cloning and functional analysis of a new activin beta subunit: a dorsal mesoderm-inducing activity in Xenopus. Biochemical and Biophysical Research Communications 1995210 581-588.

16 Mathews LS \& Vale WW. Expression cloning of an activin receptor, a predicted transmembrane serine kinase. Cell 199165 973-982.

17 Attisano L, Wrana JL, Cheifetz S \& Massague J. Novel activin receptors: distinct genes and alternative mRNA splicing generate a repertoire of serine/threonine kinase receptors. Cell 199268 97-108.

18 Robertson DM, Klein R, de Vos FL, McLachlan RI, Wettenhall RE, Hearn MT et al. The isolation of polypeptides with FSH suppressing activity from bovine follicular fluid which are structurally different to inhibin. Biochemical and Biophysical Research Communications 1987149 744-749.

19 Ueno N, Ling N, Ying SY, Esch F, Shimasaki S \& Guillemin R. Isolation and partial characterization of follistatin: a single-chain $M_{\mathrm{r}} 35000$ monomeric protein that inhibits the release of folliclestimulating hormone. Proceedings of the National Academy of Sciences of the USA $1987848282-8286$.

20 Nakamura T, Takio K, Eto Y, Shibai H, Titani K \& Sugino H. Activin-binding protein from rat ovary is follistatin. Science 1990 $247836-838$.

21 de Winter JP, ten Dijke P, de Vries CJ, van Achterberg TA, Sugino $\mathrm{H}$, de Waele $\mathrm{P}$ et al. Follistatins neutralize activin bioactivity by inhibition of activin binding to its type II receptors. Molecular and Cellular Endocrinology 1996116 105-114.

22 Hashimoto O, Nakamura T, Shoji H, Shimasaki S, Hayashi Y \& Sugino H. A novel role of follistatin, an activin-binding protein, in the inhibition of activin action in rat pituitary cells. Endocytotic degradation of activin and its acceleration by follistatin associated with cell-surface heparan sulfate. Journal of Biological Chemistry $199727213835-13842$.

23 de Kretser DM \& Phillips DJ. Mechanisms of protein feedback on gonadotropin secretion. Journal of Reproduction and Immunology 1998 $391-12$.

24 Welt CK, Lambert-Messerlian G, Zheng W, Crowley WF Jr \& Schneyer AL. Presence of activin, inhibin, and follistatin in 
epithelial ovarian carcinoma. Journal of Clinical Endocrinology and Metabolism 199782 3720-3727.

25 Meunier H, Rivier C, Evans RM \& Vale W. Gonadal and extragonadal expression of inhibin alpha, beta $\mathrm{A}$, and beta $\mathrm{B}$ subunits in various tissues predicts diverse functions. Proceedings of the National Academy of Sciences of the USA 198885 247-251.

26 Michel U, Rao A \& Findlay JK. Rat follistatin: ontogeny of steadystate mRNA levels in different tissues predicts organ-specific functions. Biochemical and Biophysical Research Communications $1991180223-230$.

27 Tuuri T, Eramaa M, Hilden K \& Ritvos O. The tissue distribution of activin beta A- and beta B-subunit and follistatin messenger ribonucleic acids suggests multiple sites of action for the activinfollistatin system during human development. Journal of Clinical Endocrinology and Metabolism 199478 1521-1524.

28 de Kretser DM, Hedger MP \& Phillips DJ. Activin A and follistatin: their role in the acute phase reaction and inflammation. Journal of Endocrinology 1999 161 195-198.

29 Munz B, Hubner G, Tretter Y, Alzheimer C \& Werner S. A novel role of activin in inflammation and repair. Journal of Endocrinology 1999161 187-193.

30 Inoue S, Orimo A, Hosoi T, Ikegami A, Kozaki K, Ouchi Y et al. Demonstration of activin-A in arteriosclerotic lesions. Biochemical and Biophysical Research Communications 1994205 441-448.

31 Matsuse T, Ikegami A, Ohga E, Hosoi T, Oka T, Kida K et al. Expression of immunoreactive activin A protein in remodeling lesions associated with interstitial pulmonary fibrosis. American Journal of Pathology 1996148 707-713.

32 Sugiyama M, Ichida T, Sato T, Ishikawa T, Matsuda Y \& Asakura $\mathrm{H}$. Expression of activin A is increased in cirrhotic and fibrotic rat livers. Gastroenterology 1998114 550-558.

33 Lai M, Sirimanne E, Williams CE \& Gluckman PD. Sequential patterns of inhibin subunit gene expression following hypoxicischemic injury in the rat brain. Neuroscience 199670 10131024.
34 Michel U, Schneider O, Kirchhof C, Meisel S, Smirnov A, Wiltfang J et al. Production of follistatin in porcine endothelial cells: differential regulation by bacterial compounds and the synthetic glucocorticoid RU 28362. Endocrinology 1996137 4925-4934.

35 Sambrook JFE \& Maniatis T. Molecular Cloning. New York: Cold Spring Harbor Laboratory Press, 1989.

36 Michel U, Albiston A \& Findlay JK. Rat follistatin: gonadal and extragonadal expression and evidence for alternative splicing. Biochemical and Biophysical Research Communications 1990173 401-407.

37 Nakatani A, Shimasaki S, Depaolo LV, Erickson GF \& Ling N. Cyclic changes in follistatin messenger ribonucleic acid and its protein in the rat ovary during the estrous cycle. Endocrinology $1991129603-611$.

38 Li MD, DePaolo LV \& Ford JJ. Expression of follistatin and inhibin/ activin subunit genes in porcine follicles. Biology of Reproduction $199757112-118$.

39 Loria P, Petraglia F, Concari M, Bertolotti M, Martella P, Luisi S et al. Influence of age and sex on serum concentrations of total dimeric activin A. European Journal of Endocrinology 1998139 487-492.

40 Klein R, Robertson DM, Shukovski L, Findlay JK \& de Kretser DM. The radioimmunoassay of follicle-stimulating hormone (FSH)suppressing protein (FSP): stimulation of bovine granulosa cell FSP secretion by FSH. Endocrinology 1991128 1048-1056.

41 Krieglstein K, Suter-Crazzolara C, Fischer WH \& Unsicker K. TGFbeta superfamily members promote survival of midbrain dopaminergic neurons and protect them against MPP+ toxicity. EMBO Journal $199514736-742$.

42 Phillips DJ, Brauman JN, Mason AJ, de Kretser DM \& Hedger MP. A sensitive and specific in vitro bioassay for activin using a mouse plasmacytoma cell line, MPC-11. Journal of Endocrinology 1999 $162111-116$

Received 26 October 1999

Accepted 3 February 2000 